\title{
Pendidikan Karakter Berbasis Islam melalui Program Cinta Rosul pada Anak Taman Kanak-Kanak
}

\author{
Iske Diana Towoliu ${ }^{1 凶}{ }^{\bowtie}$, Sofia Hartati ${ }^{2}$ Hapidin $^{3}$ \\ Pendidikan Anak Usia Dini, Universitas Negeri Jakarta \\ DOI: $10.31004 /$ obsesi.v5i1.618
}

\begin{abstract}
Abstrak
Tujuan penelitian untuk mendeskripsikan gambaran pendidikan karakter berbasis Islam, peran guru, lingkungan, dan hambatan pelaksanaan kegiatan pendidikan karakter di TK Izzati Kecamatan Bekasi Selatan. Metode penelitian fenomenologi dengan teknik pengunpulan data adalah wawancara, observasi dan dokumentasi. Analisis data menggunakan model Miles dan Huberman. TK Izzati menjalankan pendidikan karakter berbasis Islam yang dinamakan Program Cinta Rosul. Peran guru sebagai pembimbing seperti membimbing anak berwudhu, sebagai teladan cara mengucapkan salam yang baik, sebagai sumber ilmu pengetahuan tentang ciptaan Allah, dan sebagai pembelajar guru mengamati sikap dan perilaku anak. Anak menjaga kebersihan lingkungan sekolah dengan membuang sampah pada tempatnya. Guru dan anak-anak bersama-sama membangun lingkungan sosial yang islami dan saling menghargai satu sama lain. Hambatan pembelajaran adalah tidak tersedianya area sekolah yang memungkinkan anak bermain bola kaki, dan kompetensi guru kurang memadai yakni guru tidak memiliki latar belakang pendidikan anak usia dini.
\end{abstract}

Kata Kunci: pendidikan karakter; cinta rosul; islami.

\begin{abstract}
The purpose of the study was to describe the description of Islamic-based character education, the role of the teacher, the environment, and obstacles in implementing character education activities in Izzati Kindergarten, South Bekasi District. Phenomenology research methods with data collection techniques are interviews, observation and documentation. Data analysis using the Miles and Huberman models. Izzati Kindergarten runs an Islambased character education called the Cinta Rosul Program. The teacher's role as a guide is like guiding an ablution child, as an example of how to say good greetings, as a source of knowledge about God's creation, and as a learner the teacher observes the child's attitude and behavior. Children maintain the cleanliness of the school environment by throwing trash in its place. Teachers and children together build an Islamic social environment and respect each other. Barriers to learning are the unavailability of school areas that allow children to play footballs, and teacher competence is inadequate ie the teacher does not have an early childhood education background.
\end{abstract}

Keywords: character education; cinta rosul; islamic.

Copyright (c) 2020 Iske Diana Towoliu, Sofia Hartati, Hapidin

$\square$ Corresponding author :

Email Address : isdianapambudi@gmail.com (Jl. Rawamangun Muka, Jakarta Timur)

Received tanggal bulan tahun, Accepted tanggal bulan tahun, Published tanggal bulan tahun 


\section{PENDAHULUAN}

Keterbukaan informasi di era digital saat ini memungkinkan berbagai informasi dengan mudah diakses oleh setiap orang, termasuk anak-anak yang belum memiliki kemampuan yang cukup untuk memilah-milah informasi dengan baik. Hal tersebut menimbulkan pengaruh negatif bagi perkembangan anak-anak dalam bentuk penyimpangan perilaku yaitu adanya anak yang suka memukul teman, malas, berbohong, egois dan lain sebagainya. Oleh karena itu sudah selayaknya pendidik dan orang tua berupaya membangun karakter anak sejak dini yang bertujuan untuk menanamkan nilainilai agama, moral dan etika yang berlaku dalam lingkungannya.

Menyaksikan kenyataan itu dan terinspirasi oleh penelitian sebelumnya yaitu bahwa agama dapat menjadi motor penggerak dalam membangun spiritual, moral, sosial, dan kultural melalui pembelajaran non-kurikuler yang melibatkan orang tua dan guru yang berperan sebagai teladan dan sebagai pembimbing anak didik (Thanissaro, 2010:175-187). Agama memberikan pengetahuan mengenai hal baik-buruk, boleh-dilarang dan keyakinan adanya Tuhan yang berkuasa mengatur kehidupan manusia. Sehubungan dengan itu, maka peneliti berupaya untuk memperoleh gambaran bahwa agama Islam dapat menjadi faktor dominan atau sebagai landasan utama bagi orangtua maupun guru dalam rangka membangun karakter anak didik melalui pendidikan karakter di sekolah. Pendidikan juga harus berkontribusi pada pengetahuan tentang bagaimana cara mempengaruhi dan mengendalikan sifat kodrati buruk (vice) dan jahat (evil) melalui pendidikan karakter sejak dini yang merupakan kontribusi signifikan bagi pendidikan karakter. Dengan memperhatikan sifat kodrati buruk dan jahat pada anak usia dini, pendidikan karakter dapat meminimalkan resiko munculnya sikap dan perilaku buruk dan jahat ketika mereka dewasa. (Gilead, 2011:271-284). Krisis karakter yang terjadi yang terjadi di Amerika Serikat disebabkan adanya pemahaman yang tidak tepat terhadap konsep dasar karakter, adanya ketidaksesuaian antara karakter yang dibangun dengan nilai-nilai manusia yang mendasar, dan adanya campur tangan pemerintah yang berlebih terhadap pendidikan anak (Ryan, 2013:145). Pendidikan anak yang dilakukan pemerintah Amerika Serikat dan pemerintah Rusia dalam memberikan pelayanan pendidikan bagi keluarga berpenghasilan rendah nyatanya lebih menekankan pemberian pelayanan kesehatan ketimbang pendidikan karakter (Glanzer, 2003:304). Kedua penelitian tersebut menyimpulkan bahwa bahwa pendidikan yang selama ini berjalan masih kurang memberikan perhatian pada pendidikan karakter anak.

Berdasarkan penelitian-penelitian sebelumnya menggugah hati peneliti untuk melakukan penelitian di TK Izzati dengan fokus "Pendidikan karakter berbasis Islam di TK Izzati." Dengan rumusan masalah penelitian ini adalah sebagai berikut: (1) bagaimana gambaran pendidikan karakter di TK Izzati?, (2) bagaimana peranan guru dalam melaksanakan pendidikan karakter berbasis Islam?, (3) bagaimana lingkungan belajar yang disiapkan untuk mendukung proses pengajaran dalam pendidikan karakter berbasis Islam di TK Izzati?, (4) Apakah yang menjadi hambatan dalam pelaksanaan pendidikan karakter berbasis Islam di TK Izzati?. Peneliti membatasi pada empat rumusan tersebut karena keterbatasan waktu dan biaya. Tujuan penelitian ini: (1) mendeskripsikan pendidikan karakter di TK Izzati, (2) )mendeskripsikan peran guru dalam melaksanakan pendidikan karakter berbasis Islam di TK Izzati, (3) mendeskripsikan lingkungan yang dibangun untuk proses pembelajaran dalam pendidikan karakter berbasis Islam di TK Izzati,(4) mendeskripsikan hambatan-hambatan pelaksanaan pendidikan karakter berbasis Islam di TK Izzati.

Pendidikan merupakan suatu proses penggalian dan pengolahan pengalaman generasi sebelumnya yang harus dipertahankan dan dikembangkan secara terus-menerus. Pengalaman sebagai sumber pengetahuan tentang nilai-nilai yang patut dipertahankan dan dikembangkan dari satu generasi ke generasi berikutnya (Wasitohadi, 2017:49-61). Pendidikan karakter adalah program yang diprakarsai oleh sekolah, yang dirancang untuk 
membentuk secara langsung dan sistematis perilaku kaum muda (Lockwood, 2009:100). Pendidikan karakter merupakan upaya untuk membangun kepribadian yang utuh dan mendalam bagi seorang individu maupun masyarakat (Rasyad, 2015:51). Pendapat tersebut memaknai bahwa pendidikan karakter adalah usaha untuk membangun peserta didik menjadi manusia seutuhnya yang memiliki kecerdasan emosional dan spiritual sehingga mampu bertindak dan mengambil keputusan secara bijak berdasarkan nilai-nilai etika inti yaitu antara lain rasa hormat, peduli, jujur, toleransi dan berbagi. Tujuan pendidikan karakter adalah untuk membangun nilai-nilai karakter yang terintegrasi dan mengoreksi berbagai perilaku negatif peserta didik melalui aktivitas pembelajaran di sekolah. Berdasarkan beberapa pendapat diatas maka dapat disimpulkan bahwa pendidikan karakter merupakan suatu usaha gerakan pendidikan untuk menanamkan, membentuk, membangun dan memberdayakan potensi karakter yang sudah ada pada peserta didik seperti jujur, sabar, tolong-menolong, tanggung jawab, berani, kerja sama dan disiplin, yang dirancang secara sistematis dan terprogram oleh pendidik yang diprakarsai sekolah dan penyelenggara negara serta melibatkan masyarakat.

Pendidikan karakter dalam pendidikan Islam merupakan aspek penting dalam kehidupan beragama bagi umat Islam untuk membangun karakter pemeluknya. Pendidikan Berbasis Islam adalah proses oleh seorang ustadz/guru yang meliputi aspek jasmani rohani, dan akal peserta didik agar tumbuh dan berkembang secara alamiah menuju terbentuknya keluarga dan masyarakat yang Islam (Fathurrohman, Suryana, \& Fatriany, 2013:37). Pendidikan Islam ialah bimbingan yang diberikan oleh seseorang kepada seseorang agar ia berkembang secara maksimal sesuai dengan ajaran Islam (Tafsir, 2008:32).

Berdasarkan beberapa pendapat diatas maka dapat disimpulkan bahwa pendidikan berbasis Islam merupakan suatu aktivitas ustadz/guru berupa bimbingan yang terencana dalam suatu sistem pembelajaran yang ditujukan kepada peserta didik agar dapat tumbuh dan berkembang sesuai dengan nilai-nilai ajaran Islam yang tertuang dalam Al Quran dan Hadist, dan sesuai dengan fitrahnya sebagai manusia. Uztad/guru dalam pendidikan berbasis Islam harus memenuhi kompetensi bidang pendidikan dan pengetahuan mengenai agama Islam. Selain itu uztad/guru harus memiliki kepribadian yang baik karena harus menjadi teladan bagi anak didiknya.

Peran guru dalam mencapai keberhasilan pendidikan berbasis Islam merupakan salah satu faktor utama yang menentukan, oleh karena itu kompetensi pendidik harus memenuhi persyaratan yang cukup untuk terciptanya pendidikan yang berkualitas. Profesionalisme pendidik anak usia dini dapat dilihat dari kualifikasi akademik dan pengalaman mengajar mereka (Kurniawati, Haenilah, \& Fatmawati, 2013:). "Jika kita dapat menemukan guru yang memiliki kemampuan luarbiasa dan layak menjadi model, maka kita dapat menjamin bahwa program pendidikan anak berbakat akan eksis" (Idris, 2014:147). Dengan demikian lembaga pendidikan harus mengutamakan upaya peningkatan kualitas guru agar dapat memberikan pelayanan pendidikan yang maksimal.

Lingkungan belajar merupakan sarana yang dengannya para pelajar dapat mencu rahkan dirinya untuk beraktivitas, berkreasi, termasuk melakukan berbagai manipulasi banyak hal hingga mereka mendapatkan sejumlah perilaku baru dari kegiatannya itu" (Mariyana, Nugraha, \& Yeni, 2013:17). Agar pendidikan berbasis Islam dapat berlangsung, maka penataan lingkungan harus mencerminkan suasana yang islami.

Pendidikan anak usia dini adalah pendidikan terhadap anak pada rentang usia 2-6 tahun, disebut juga sebagai masa problematis/sulit dididik atau usia bermain karena sebagian beşar hidup anak dihabiskan untuk bermain, para pendidik menyebutnya masa persiapan maşuk sekolah dasar, usia prakelompok karena anak-anak mempelajari dasardasar perilaku sosial, usia penjelajah dan usia bertanya, berani dan senang mencoba hal-hal baru (Marliani, 2015:133). Usia 0-6 tahun merupakan usia penting bagi pengembangan intelegensia permanen dirinya, mereka juga mampu menyerap informasi yang sangat tinggi 
(Sujiono, 2009:7). Oleh karena itu dalam menghadapi anak usia tersebut, seorang guru harus memahami perilaku anak dengan baik agar dapat memberikan bimbingan yang tepat.

Pada usia tersebut, anak mengalami pertumbuhan dan perkembangan yang cepat. Pertumbuhan anak berkaitan dengan perubahan secara kuantitatif, yaitu peningkatan ukuran dan struktur sedangkan perkembangan anak merupakan suatu perubahan yang bersifat kualitatif, perkembangan tidak ditekankan pada segi material, melainkan pada segi fungsional (Aghnaita, 2018:221). Pertumbuhan berkaitan dengan bertambahnya perangkat fisik yang makin baik, sedangkan perkembangan berkaitan dengan fungsinya.

Hasil wawancara dengan Kepala Sekolah TK Izzati Bekasi menunjukkan bahwa pembelajaran TK Izzati lebih mengutamakan pendidikan karakter berbasis islam. Oleh karena itu, TK Izzati memandang pendidikan karakter sebagai pendidikan karakter berbasis Islam yaitu Pendidikan karakter yang berpijak pada landasan moral agama Islam yang meliputi aspek aqidah, ibadah, kemasyarakatan, akhlak (budi pekerti), kepribadian, intelektualitas, dan fisik.

Dari hasil observasi terlihat seorang guru mengajak semua anak duduk bersama membentuk lingkaran di ruangan besar sedang berzikir, beristighfar, bershalawat, membaca surat-surat pendek, membaca doa-doa harian, menyebutkan nama-nama nabi, menyebutkan nama-nama malaikat, asmaul husna dengan lagu dan membaca hadist kebersihan, hadist kemuliaan ibu, hadist larangan marah, hadist larangan makan dan minum sambil berdiri mengikuti arahan guru. Guru lainnya turut terlibat sebagai pengawas sambil mengamati proses pembelajaran. Tujuan kegiatan tersebut adalah untuk menanamkan aqidah dan membiasakan anak melakukan ibadah dan perilaku islami.

Penelitian ini akan memberikan hasil berupa gambaran pendidikan karakter berbasis Islam yang dapat menjadi acuan bagi para pendidik untuk mengoptimalkan pendidikan karakter anak usia dini. Dengan hasil penelitian ini, peneliti berharap anak didik mempunyai landasan spiritual yang kuat yang akan menjaganya agar tetap berada pada jalur yang benar sesuai dengan ajaran agama Islam.

\section{METODOLOGI}

Metode yang digunakan adalah metode penelitian kualitatif dengan pendekatan fenomenologis yakni peneliti berusaha untuk memperoleh pemahaman mengenai konsep dan praktek pendidikan karakter berbasis Islam di TK Izzati Bekasi yang beralamat di Jl. Arjuna I No 10 Perumahan Bumi Satria Kencana, Kota Bekasi. Pada penelitian kualitatif, peneliti mengumpulkan data mengenai pendidikan karakter berbasis Islam di TK Izzati Bekasi melalui observasi, wawancara, dokumentasi dan catatan lapangan yang berlangsung sejak tanggal 4 November 2019 sampai dengan 22 November 2019. Peneliti melakukan wawancara terhadap Kepala Sekolah, guru kelas dan anak didik.

Penelitian ini melalui tahapan persiapan, pelaksanaan dan pengelolaan data. Adapun teknik yang digunakan dalam pengumpulan data penelitian meliputi: observasi, wawancara dan studi dokumen dengan menggunakan alat bantu berupa pedoman wawancara dan pedoman observasi.

Dalam penelitian ini, analisis data yang dipakai adalah model Miles dan Huberman yang membagi analisis data kualitatif dalam tiga aktivitas, yaitu kondensasi data (data condensation), penyajian data (data display), dan penarikan kesimpulan/verifikasi (conclusion: drawing/verivying) (Miles, 2014:12-13). 


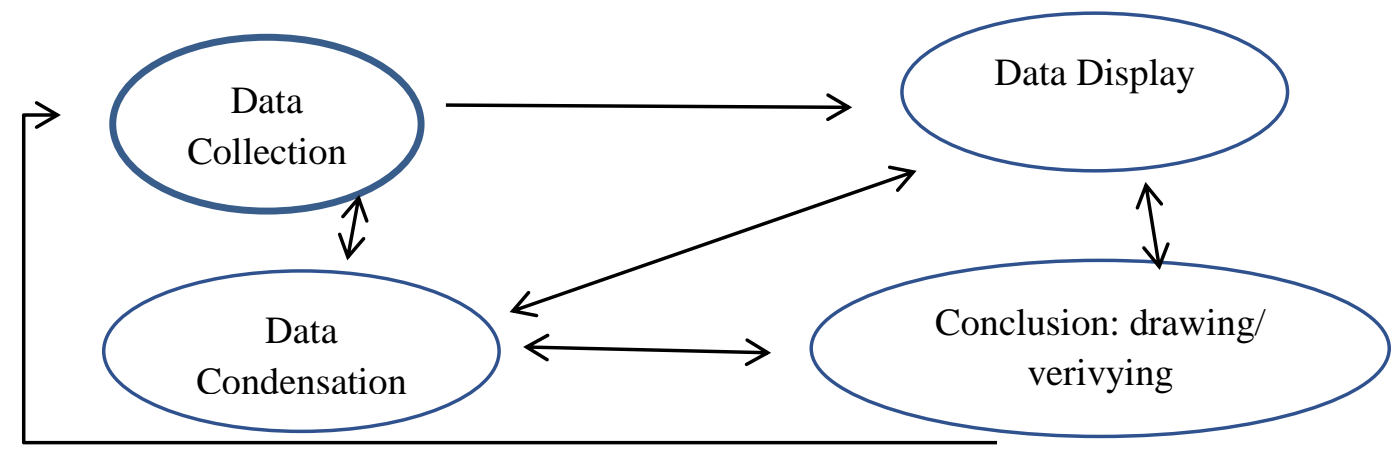

Gambar 1: Skema prosedur analisis data

Ketiga aktivitas tersebut berlangsung terus menerus selama proses penelitian berlangsung. Pilihan peneliti tentang bagian-bagian data yang dikode, mana yang dibuang, pola-pola mana yang meringkas sejumlah bagian yang tersebar, cerita-cerita apa yang sedang berkembang. Maka dalam penelitian ini, peneliti akan memberi perhatian khusus terhadap bagian data pendidikan karakter di TK Izzati, peran guru dalam melaksanakan pendidikan karakter berbasis Islam, lingkungan belajar yang dibangun untuk mendukung proses pembelajarn kaitannya dengan pendidikan karakter berbasis Islam, dan hambatanhambatan pelaksanaan pendidikan karakter berbasis Islam di TK Izzati.

\section{HASIL DAN PEMBAHASAN}

Berdasarkan hasil wawancara dengan Kepala Sekolah bahwa TK Izzati menjalankan suatu program pembelajaran yang bernama Program Cinta Rosul yaitu suatu program pembelajaran yang berupaya menanamkan keteladanan Rosulullah pada anak di TK Izzati yang mencakup aspek aqidah, ibadah, kemasyarakatan, akhlak, kepribadian, intelektual dan fisik.

Berdasarkan hasil observasi 4 November 2019 terilihat proses pembelajaran Program Cinta Rosul berlangsung dalam satu ruangan besar dengan melibatkan seluruh anak usia 4-6 tahun (Kelompok Makkah dan Madinah) dan seluruh guru selama 150 menit. Guru-guru membentuk satu tim guru dengan menetapkan seorang guru piket sebagai kordinator untuk menjalankan proses pembelajaran belajar. Guru piket mengawali proses pembelajaran dengan mengajak semua anak brsama-sama membaca istighfar, dzikir, shalawat dengan mengikuti lagu, kemudian melanjutkannya dengan melakukan berbagai kegiatan yang telah dipersiapkan untuk hari itu. Guru piket sebagai kordinator yang mengendalikan proses pembelajaran, sedangkan guru yang lain bersama-sama mendampingi, mengawasi dan mengamati perilaku anak-anak. Dengan demikian beban tanggung jawab guru terbagi merata dan memudahkan guru memahami permasalahan belajar anak. Hal ini sejalan dengan metode team teaching (pembelajaran beregu) yaitu metode pembelajaran yang dilaksanakan oleh lebih dari satu orang guru dalam satu kelompok siswa yang sama untuk meningkatkan hasil belajar siswa (Damanik, Siahaan, \& Tamba, 2018:115).

Hasil observasi 7 November terlihat anak-anak dan guru-guru duduk membentuk lingkaran di lantai beralaskan karpet berwarna-warni ibu guru menunjuk salah satu anak memimpin doa pagi. Pemimpin dengan percaya diri memimpin teman-temannya membaca istighfar, zikir, sholawat dengan mengikuti lagu "Ya Nabi Salam Alaika" yang dinyanyikan oleh Haddad Alwi.

Hasil observasi 8 November terlihat pada waktu anak-anak memasuki pintu pagar ke area sekolah, mereka memberi salam sambil mencium tangan ibu guru kemudian melepaskan sepatu dan meletakannya di rak sepatu yang terletak di sisi kanan halaman sekolah dan menggantungkan tasnya ketempat yang sudah tertempel nama dan foto diatasnya. 
Hasil observasi 12 November anak-anak mengenakan seragam olah raga, karena setiap hari selasa anak-anak melakukan motorik kasar. Anak-anak dan guru sudah membentuk lingkaran, karena mau istighfar, berzikir, bershalawat mengikuti lagu, guru menunjuk salah satu anak dari kelompok Madinah menjadi pemimpin pada pagi ini. Selanjutnya pemimpin mengarahkan teman-temannya membaca surat Al Lahab, An Nasr dan ayat kursi. Lalu menyebutkan rukun islam dan rukun iman. Guru melatih mereka menjadi pemimpin, karena meneladani sifat Rasulullah, seperti memiliki jiwa kepemimpinan, bertanggung jawab dan dapat mengambil keputusan.

Dari hasil wawancara dengan dua anak kelompok Makkah peneliti menemukan bahwa anak suka bershalawat karena memakai lagu, menyukai kebersihan dan senang belajar bersama teman. Hal tersebut menunjukkan materi dan jenis kegiatan di TK Izzati jelas mengacu pada Kurikulum 2013 PAUD. TK Izzati menggunakan pendekatan pembelajaran melalui tujuh aspek pendidikan Islam yaitu aqidah, ibadah, kemasyarakatan, akhlak, kepribadian, intelektualitas, dan fisik.

Aqidah pada anak usia dini ditunjukan ketika sedang makan, air minum tumpah ke karpet, anak berucap Astatagfirullah hal adzim, airnya tumpah. Hal ini menunjukkan bahwa anak-anak terbiasa menghubungkan setiap kejadian yang mereka alami dengan menyebut nama Allah SWT. Hal ini sejalan dengan yang dikemukakan oleh Thanissaro bahwa agama dapat menjadi motor penggerak dalam membangun spiritual, moral, sosial, dan kultural (Thanissaro, 2010:175-187).

Ibadah pada anak usia dini ditunjukan melalui membiasakan diri sholat berrjama'ah setiap hari Jumat di sekolah sebagai ungkapan terima kasih memohon keselamatan pada Allah. Dengan pembiasaan melakukan ibadah, anak-anak terbiasa memberikan santapan bagi aqidah merupakan cerminan dari aqidah (Suwaid, 2008:217).

Kemasyarakatan yang dilakukan anak usia dini berdasarkan hasil pengamatan terlihat pada saat anak membantu mengobati temannya yang terluka dengan spontan mengambil P3K, dan perilaku membersihkan lingkungan secara bersama-sama seperti membuang sampah pada tempat sampah menunjukkan adanya interaksi sesama anak dan kerjasama dalam kelompok anak-anak (Anwar, 2015).

Akhlak anak tercermin pada saat anak secara spontan mengucapkan istighfar saat menyadari telah melakukan kesalahan, membantu teman, berani tampil menjadi pemimpin bagi temannya, memiliki rasa disiplin dan selalu menjaga kebersihan. Hal ini menunjukkan bahwa anak mampu mengembangkan sikap berani dalam kebenaran serta bijaksana (Mahmud, 2017:64).

Kepribadian pada anak usia dini ditunjukan terlihat dari adanya perbedaan anak dalam bekerjasama merapihkan mainan, ada beberapa anak yang tidak mau merapihkan mainan dengan alasan bahwa mereka tidak menggunakan mainan. Hal tersebut menunjukkan adanya ciri khas kepribadian anak sebagai keseluruhan sikap, ekspresi, perasaan, temperamen, dan perilaku yang khas dari seseorang yang membedakannya dengan orang lain (Ja'far, 2017:211).

Intelektualitas terlihat pada saat anak usia dini dapat memahami mengapa batu tenggelam dalam air sedangkan kertas mengapung. Hal ini merupakan indikator kecerdasan yaitu memiliki sains yang banyak dan berkualitas tinggi (Tafsir, 2008:43).

Fisik terlihat anak-anak mengikuti kegiatan bermain bola basket sebagai upaya menjaga kesehatan fisik.

Berdasarkan analisis hasil penelitian diatas, maka dapat dirumuskan teori substantif sebagai berikut: pembiasaan perilaku islami anak usia dini dalam Program Cinta Rosul membentuk perilaku anak yang mecirikan karakter islami. Perilaku yang terbentuk adalah selalu mengucap syukur atas kebaikan/kenikmatan, ibadah sholat, membantu teman sebagai sesama anggota masyarakat, akhlak (budi pekerti) yang baik, kepribadian yang kuat, intelektualitas yang tinggi dan kesadaran kesehatan fisik. 
Berdasarkan hasil dokumentasi dan observasi 19 November 2019 terlihat guru TK Izzati memperkenalkan pengetahuan tentang tanaman dan bagian-bagiannya sambil mengingatkan bahwa tanaman adalah ciptaan Allah. Ibu guru mengucap basmallah saat memulai dan hamdallah saat mengakhiri kegiatan diikuti oleh anak-anak. Seorang guru harus memahami kompetensi dasar yang akan dimiliki oleh peserta didik, apa yang harus dilakukan, apa yang harus dipelajari, bagaimana mempelajarinya, serta bagaimana guru mengetahui bahwa peserta didik telah menguasai kompetensi tertentu (Zein, 2016:280).

Sebagai teladan guru TK Izzati menunjukkan sikap, perilaku, penampilan fisik dan cara berkomunikasi yang menarik bagi anak-anak. Pada saat proses pembelajaran, guru TK Izzati menunjukkan keteladanan berbicara dengan bahasa yang lembut, suara yang jelas dengan diiringi sikap ramah pada saat menyambut kedatangan anak, bercerita dan memberi pengertian pada anak yang rewel. Guru haruslah menjadi teladan, seorang model sekaligus mentor dari peserta didik di dalam mewujudkan perilaku yang berkarakter (Wardhani \& Wahono, 2017:57).

Sebagai pembimbing, guru TK Izzati memiliki pemahaman tentang anak-anak yang sedang dalam bimbingannya yaitu tentang gaya dan kebiasaan anak, memahami potensi dan bakat anak dan dapat menentukan bagaimana teknik dan jenis bimbingan yang harus diberikan sehingga anak bersedia mengikuti proses pembelajaran dengan antusias. Guru sebagai pembimbing memberi bantuan kepada individu secara berkesinambungan, agar individu tersebut dapat memahami dirinya sehingga ia sanggup mengarahkan dirinya dan dapat bertindak wajar (Juhji, 2016:55)

Sebagai pembelajar guru dituntut untuk selalu menambah pengetahuan dan ketrampilan. Guru di TK Izzati belajar dan mengasah kemampuannya sebagai guru profesional pada saat pembelajaran berlangsung dengan cara mengamati proses pembelajaran untuk mendapatkan masukan. Ketika guru dikatakan sebagai pembelajar maka dia akan terus belajar sepanjang hayatnya (Richardo, 2016:778).

Dari hasil dokumentasi 8 november 2019 terlihat aspek utama lingkungan fisik yang selalu menjadi perhatian guru adalah kebersihan lingkungan sekolah sebagaimana terlihat adanya aktivitas guru yang selalu mengingatkan anak-anak tentang hadist riwayat muslim kebersihan "At thuhuuru syathrul imaan" artinya kebersihan sebagian dari iman. Selanjutnya, untuk pembiasaan perilaku kebersihan, setiap hari guru mengajak mereka melakukan kegiatan "operasi semut" yaitu kegiatan merapihkan dan membersihkan lingkungan tempat bermain dengan cara bersama-sama mengembalikan peralatan mainan ke tempat semula dan menyapu lantai yang dilakukan diakhir waktu sekolah. Hal ini sesuai dengan Shalihah dan Salamah yang berpendapat bahwa guru dapat melibatkan anak dalam kegiatankegiatan terkait dengan pemeliharaan kebersihan lingkungan seperti menyapu lantai sekolah dan lain-lain (Shalihah \& Salamah, 2017:149).

Guru dan anak-anak bersama-sama membangun lingkungan sosial yang islami dengan membiasakan mengucapkan kalimat-kalimat thayyibah, bersikap sopan dan saling menghargai satu sama lain yang terlihat dari anak yang mengucapkan "Astagfirullah hal adzim", perilaku membantu teman dan adanya ucapan terima kasih karena telah menerima bantuan teman sehingga terbangun lingkungan sosial yang meberikan rasa aman, dan senang bagi anak. Dengan demikian anak mau mengikuti proses belajar dengan tanpa merasa terbebani bahwa mereka sedang belajar. Lingkungan menyenangkan dalam konteks PAUD adalah segala sesuatu, baik makhluk hidup maupun benda mati, di sekitar anak yang dapat membuatnya senang (Hidayatulloh, 2014:153).

Berdasarkan hasil wawancara 4 November 2019 dengan Kepala Sekolah menemukan hambatan dalam pelaksanaan pendidikan karakter berbasis Islam di TK Izzati adalah tidak tersedia area sekolah yang memungkinkan anak bermain secara leluasa untuk mengembangkan kemampuan fisik motorik kasar. Kondisi tersebut menunjukkan bahwa TK Izzati belum menyediakan ruang terbuka sesuai kriteria luas ruang terbuka untuk bermain yaitu tersedianya ruangan terbuka (speelood) yang ideal untuk kegiatan olah raga 
ringan, senam atau permainan, adalah $12 \times 10 \mathrm{~m} 2=120 \mathrm{~m} 2$ dengan bentuk ruang sebaiknya mendekati bujursangkar, segienam, atau bulat (Ariestadi, 2010: 216).

Hambatan lainnya adalah pemenuhan kriteria kompetensi guru yang ada di TK Izzati dari segi kualifikasi akademis masih belum mencukupi karena latar belakang pendidikan akademisnya berasal dari pendidikan non PAUD. Pendidikan karakter bagi anak usia dini pada hakikatnya adalah upaya pendidik untuk membangun landasan karakter anak usia dini agar kelak menjadi manusia dewasa yang berakhlakul.

\section{SIMPULAN}

TK Izzati memandang pendidikan karakter sebagai pendidikan karakter berbasis Islam yaitu pendidikan karakter yang berpijak pada landasan moral agama Islam yang meliputi aspek aqidah, ibadah, kemasyarakatan, akhlak, kepribadian, intelektualitas, dan fisik. Sebagai perwujudan dari pendidikan karakter tersebut, TK Izzati menjalankan suatu program pembelajaran yang bernama Program Cinta Rosul yaitu suatu program pembelajaran yang berupaya menanamkan keteladanan Rosulullah pada anak di TK Izzati. Keteladanan tersebut antara lain meliputi kepemimpinan, kejujuran, berbicara lembut, menghormati orang tua, menghormati guru, bertanggung jawab dan mandiri.

\section{UCAPAN TERIMA KASIH}

Penulis mengucapkan terima kasih kepada segenap pimpinan dan civitas akademika Universitas Negeri Jakarta. Kepala Sekolah, guru-guru dan anak-anak TK Izzati Bekasi.

\section{DAFTAR PUSTAKA}

Aghnaita, A. (2018). Perkembangan Fisik-Motorik Anak 4-5 Tahun pada Permendikbud No. 137 Tahun 2014 (Kajian Konsep Perkembangan Anak). Al-Athfal : Jurnal Pendidikan Anak, 3(2), 219. https://doi.org/10.14421/al-athfal.2017.32-09

Anwar, S. (2015). Management of Student Development, Perspektif Al Quran dan As Sunnah. Yayasan Indragiri.

Ariestadi, D. (2010). Kajian dan Pengembangan Standar BangunanTaman Kanak-kanak Sebagai Upaya Peningkatan Mutu Pendidikan Anak Usia Dini di Indonesia. Jurnal Teknologi Dan Kejuruan, 33(2), 211-222. https://doi.org/DOI: http://dx.doi.org/10.17977/tk.v33i2.3057

Damanik, R. Y. S., Siahaan, M. F., \& Tamba, K. P. (2018). Penerapan Metode Team Teaching Dalam Pembelajaran Matematika Di Sma Kristen Abc Sukoharjo [the Implementation of the Team Teaching Method in Learning Mathematics At Abc Christian High School in Sukoharjo]. JOHME: Journal of Holistic Mathematics Education, 1(2), 114. https:// doi.org/10.19166/johme.v1i2.815

Fathurrohman, H. P., Suryana, A., \& Fatriany, F. (2013). Pengembangan Pendidikan Karakter. Rafika Aditama.

Gilead, T. (2011). Countering the Vices: On the Neglected Side of Character Education. Journal of Studies in Philosophy and Education, 30(3), 271-284. https:// doi.org/10.1007/s11217-011-9223-1

Glanzer, P. L. (2003). Did the Moral Education Establishment Kill Character? An autopsy of the Death of Character. Journal of Moral Education, 32(3), 291-306. https:/ / doi.org/10.1080/0305724032000136716

Hidayatulloh, M. A. (2014). Lingkungan Menyenangkan dalam Pendidikan Anak Usia Dini : Pemikiran Montessori. Nadwa | Jurnal Pendidikan Islam, 8(April).

Idris, M. H. (2014). Peran Guru dalam Mengelola Keberbakatan Anak (T. Luxima (ed.); Cetakan I). Luxima.

Ja'far, S. (2017). Struktur Kepribadian Manusia Perspektif Psikologi dan Filsafat. Psympathic: Jurnal Ilmiah Psikologi, 2(2), 209-221. https://doi.org/10.15575/psy.v2i2.461

Juhji. (2016). Guru, Mendidik, Mengajar, Nilai, Pembentukan Kepribadian, Panutan. Jurnal 
DOI: 10.31004/obsesi.v5i1.618

Ilmiah Pendidikan Studia Didaktika, 10, n. 01,(ISSN 1978-8169), 61.

Kurniawati, E., Haenilah, E., \& Fatmawati, N. (2013). Studi Deskriptif Profesionalisme Guru TK dalam Pembelajaran Anak Usia Dini di Kecamatan Bandar Sribhawono Kabupaten Lampung Timur. Journal of Chemical Information and Modeling, 53(9), 16891699. https:// doi.org/10.1017/CBO9781107415324.004

Mahmud, A. (2017). Akhlak Terhadap Allah Dan Rasulullah. Jurnal Wawasan Keislaman, 11(2), 57-68.

Mariyana, R., Nugraha, A., \& Yeni, R. (2013). Pengelolaan Lingkungan Belajar (Suwito (ed.); Cetakan ke). Kencana.

Marliani, R. (2015). Psikologi Perkembangan (B. A. Saebani (ed.)). Pustaka Setia.

Miles, M. B. \& A. M. H. (2014). Qualitative Data Analysis (Third). Sage.

Nurani, Y. (2009). Konsep Dasar Pendidikan Anak Usia Dini. PT Indeks.

Rasyad, A. (2015). Developing a Parenting Training Model of Character Education for Young Learners from Poor Families by Using Transformative Learning Approach. Journal: International Education Studies, 8(8), 50-56. https://doi.org/10.5539/ies.v8n8p50

Richardo, R. (2016). Program Guru Pembelajar: Upaya Peningkatan Guru Profesionalisme Guru Abad 21. Prosiding Seminar Matematika Dan Pendidikan Matematika, November, 777-785.

Ryan, K. (2013). The Failure of Modern Character Education. Journal: Revista Espanola de Pedagogia, 71(254), 141-146.

Shalihah, S., \& Salamah, S. (2017). Penanaman Nilai-Nilai Kebersihan Lingkungan Oleh Guru di MiI Hayatuddiniah Jambu Burung Kecamatan Beruntung Baru Kabupaten Banjar. AL-ADZKA, Jurnal Ilmiah Pendidikan Guru Madrasah Ibtidaiyah, VII, 145-166.

Suwaid, M. I. A. H. (2008). Cara Nabi Mendidik Anak (A. Hakim (ed.); Kedua). Al I'Tishom.

Tafsir, A. (2008). Ilmu Pendidikan dalam Perspektif Islam. Remaja Rosdakarya.

Thanissaro, P. N. (2010). Finding A Moral Homeground: Appropriately Critical Religious Education and Transmission of Spiritual Values. International Journal of Children's Spirituality, 15(2), 175-187. https:/ / doi.org/10.1080/1364436X.2010.502223

Wardhani, N. W., \& Wahono, M. (2017). Keteladanan Guru Sebagai Penguat Proses Pendidikan Karakter. Untirta Civic Education Journal, 2(1), 49-60. https://doi.org/10.30870/ucej.v2i1.2801

Wasitohadi, W. (2017). Hakekat Pendidikan dalam Perspektif John Dewey Tinjauan Teoritis. Jurnal Satya Widya, 30(1), 49. https:/ / doi.org/10.24246/j.sw.2014.v30.i1.p49-61

Zein, M. (2016). Peran guru dalam pengembangan pembelajaran. Journal UIN- Alauddin, V(2), 274-285. https://doi.org/10.24252/ip.v5i2.3480 